\title{
Impact of projected climate on wheat yield in India and its adaptation strategies
}

\section{V.P. PRAMOD, B. BAPUJI RAO, S.S.V.S. RAMAKRISHNA ${ }^{1}$, M. MUNESHWAR SINGH ${ }^{2}$, N.R. PATEL ${ }^{3}$, V.M. SANDEEP, V.U.M. RAO, P. S. CHOWDARY, V. NARSIMHA RAO and P. VIJAYA KUMAR}

\author{
Central Research Institute for Dryland Agriculture, Santoshnagar, Hyderabad - 500059 \\ ${ }^{1}$ Department of Meteorology and Oceanography, Andhra University, Visakhapatnam - 530004 \\ ${ }^{2}$ All India Coordinated Research Project on Long-Term Fertilizer Experiments, IISS, Bhopal - 462038 \\ ${ }^{3}$ Indian Institute of Remote Sensing, Dehradun - 248001 \\ Email:pramodvp1@gmail.com
}

\begin{abstract}
Wheat is highly sensitive to climate change especially temperature changes experienced in the later phase of crop season. Hence, it is of immense importance to know how and to what extent climate change will affect wheat yields and to assess the adaptive strategies for mitigating possible negative consequences on wheat production. Wheat yield responses to three future climatic periods $(2025,2050$ and 2075) were studied by driving DSSAT-Wheat (v4.5) model with daily weather from three CMIP-5 climate models' (GFDL-ESM2M, MIROC5, and NorESM1-M) as the basic input at four sites (Ludhiana, Raipur, Akola and New Delhi) representing three major wheat growing zones of the country. Projected changes in growing season (November-March) day and night temperatures at four sites differed substantially both in direction and magnitude. Day temperatures are projected to rise conspicuously at Ludhiana, representing northwest parts of the country, and moderately over central parts of India (Akola and Raipur). Positive rainfall anomalies at Ludhiana $(+76 \%)$ and negative anomalies at Raipur $(-15 \%)$ are projected in future climates. With these anticipated changes, wheat is likely to experience warmer days $\left(+1.1{ }^{\circ} \mathrm{C}\right)$ at Ludhiana and nights at Raipur $\left(+2.8^{\circ} \mathrm{C}\right)$ and more seasonal moisture availability at Ludhiana in future climates. Negative impacts of climatic change in these sites are found to be minimized by adapting one or a combination of management practices, which are site specific.
\end{abstract}

Keywords: Wheat productivity, future climates, adaptation strategies, DSSAT-Wheat

In India, wheat is the second important food crop after rice, that grown over 30 million hectares (Mha) with a production of 94 million tons (MT)(DES, 2017). The country has to produce 105 MT by 2025, demanding an average growth rate of $4 \%$ per annum (Prasad, 2011). With increasing pressure on cultivable land, there is hardly any scope to expand the area under wheat. On the other side, substantial yield gaps within wheat growing regions of the country, as well as between non-station and on-farm yields are reported. Apart from these, climate change impacts have led to a decline in productivity on Indian wheat yields (Manju Zacharias et al., 2014; Sandhu et al., 2016). The unusual warming trends during grain filling stage are causing yield declines, especially in eastern and central India (Chatrath et al., 2007). Bapuji Rao et al. (2015) identified exposure to continual minimum temperature $\left(\mathrm{T}_{\min }\right)$ exceeding $12^{\circ} \mathrm{C}$ for 6 days and terminal heat stress with maximum temperature $\left(\mathrm{T}_{\max }\right.$ ) exceeding $34{ }^{\circ} \mathrm{C}$ for 7 days during the post-anthesis period as thermal constraints in realizing potential productivity. To overcome the climatic barrier some available options include growing heat tolerant varieties, shifting sowing time, efficient nutrient management and irrigation (Nathaniel et al., 2012). In this backdrop, we attempted to study the impact on wheat yield under future climate scenarios $(2025,2050$ and 2075) at some selected sites using CERES-Wheat model and adaptation strategies.

\section{MATERIALS AND METHODS}

The long term experimental data on wheat crop for four sites viz. Ludhiana (1999-2010), Raipur (2001-2012), Akola (1998-2011) and New Delhi (1993-2009) were obtained from All India Coordinated Research Project (AICRP) on Long-Term Fertilizer Experiment (LTFE), IISS, Bhopal, Madhya Pradesh. These sites cover a wide range of soil and climatic conditions. The geographic, agro-climatic and experimental details for the four sites are given in Table 1.

CERES-Wheat (Godwin et al., 1989) embedded in the Decision Support System for Agrotechnology Transfer 
Table 1: Geographic, agro-climatic and experimental details at different sites

\begin{tabular}{|c|c|c|c|c|c|}
\hline \multicolumn{2}{|l|}{ Particulars } & Ludhiana & Raipur & Akola & New Delhi \\
\hline \multicolumn{2}{|l|}{ Latitude } & $30^{\circ} 54^{\prime}$ & $21^{\circ} 14^{\prime}$ & $20^{\circ} 42^{\prime}$ & $28^{\circ}$ \\
\hline \multicolumn{2}{|l|}{ Longitude } & $75^{\circ} 49^{\prime}$ & $81^{\circ} 42^{\prime}$ & $77^{\circ} 3^{\prime}$ & $77^{\circ}$ \\
\hline \multicolumn{2}{|l|}{ Altitude (m) } & 251 & 292 & 296 & 250 \\
\hline \multicolumn{2}{|l|}{ Wheat growing zone } & NWPZ & $\mathrm{CZ}$ & $\mathrm{PZ}$ & NWPZ \\
\hline \multicolumn{2}{|l|}{ Soil texture } & Sandy Loam & Clay Loam & Clay & Silty Clay Loam \\
\hline \multicolumn{6}{|c|}{ "Mean seasonal climate ( $r a b i)$} \\
\hline \multicolumn{2}{|l|}{$\mathrm{T}_{\max }\left({ }^{\circ} \mathrm{C}\right)$} & 22.7 & 30.3 & 32.1 & 24.6 \\
\hline \multicolumn{2}{|l|}{$\mathrm{T}_{\min }\left({ }^{\circ} \mathrm{C}\right)$} & 8.9 & 14.3 & 13.8 & 9.5 \\
\hline \multicolumn{2}{|l|}{ Rainfall(mm) } & 106 & 109 & 57 & 67 \\
\hline \multicolumn{2}{|l|}{ Sunshine (hr) } & 7.4 & 8.1 & 8.4 & 6.1 \\
\hline \multicolumn{6}{|l|}{ Experimental details } \\
\hline \multicolumn{2}{|l|}{ Experimental period } & $1999-2010$ & $2001-2012$ & $1998-2011$ & 1993-2009 \\
\hline \multicolumn{2}{|l|}{ Cultivar } & PBW-343 & GW-273 & AKW-1071 & HD-2329 \\
\hline \multicolumn{2}{|l|}{ Normal sowing time } & 06-Nov & 01-Dec & 22-Nov & 21-Nov \\
\hline \multicolumn{2}{|c|}{ Average crop duration (DAS) } & $140-150$ & $125-135$ & $120-130$ & $130-140$ \\
\hline \multirow{3}{*}{$\begin{array}{l}\text { Irrigation schedule (DAS) } \\
\text { (Excluding pre-sowing } \\
\text { irrigation) }\end{array}$} & 1. & $25-30$ & $20-25$ & $20-25$ & $20-25$ \\
\hline & 2. & $60-65$ & $40-45$ & $35-40$ & $40-45$ \\
\hline & $\begin{array}{l}3 . \\
4 . \\
5 . \\
6 .\end{array}$ & $\begin{array}{l}95-100 \\
125-130 \\
100-105\end{array}$ & $\begin{array}{l}60-65 \\
80-85 \\
85-90 \\
95-100\end{array}$ & $\begin{array}{l}50-55 \\
70-75 \\
110-115\end{array}$ & $\begin{array}{l}70-75 \\
90-95\end{array}$ \\
\hline \multicolumn{2}{|c|}{ Fertilizer rate $(100 \%)(\mathrm{N}-\mathrm{P}-\mathrm{K})$} & $150-60-30$ & $100-60-40$ & $120-60-40$ & $150-60-30$ \\
\hline \multicolumn{2}{|l|}{ Fertilizer schedule } & $\begin{array}{l}(1 / 3) \mathrm{N}+\mathrm{P}+\mathrm{K} @ \text { Sowing } \\
(2 / 3) \mathrm{N} @ 20-25 \mathrm{DAS}\end{array}$ & $\begin{array}{l}(1 / 2) \mathrm{N}+\mathrm{P}+\mathrm{K} @ \text { Sowing } \\
(1 / 4) \mathrm{N} @ 20-25 \mathrm{DAS} \\
(1 / 4) \mathrm{N} @ 40-45 \mathrm{DAS}\end{array}$ & $\begin{array}{l}(1 / 2) \mathrm{N}+\mathrm{P}+\mathrm{K} @ \text { Sowing } \\
(1 / 2) \mathrm{N} @ 20-25 \mathrm{DAS}\end{array}$ & $\begin{array}{l}(1 / 3) \mathrm{N}+\mathrm{P}+\mathrm{K} @ \text { Sowing } \\
(2 / 3) \mathrm{N} @ 20-25 \mathrm{DAS}\end{array}$ \\
\hline
\end{tabular}

NWPZ-North West Plain Zone; CZ-Central Zone, PZ-Peninsular Zone; DAS-Days after sowing;

"-Seasonal mean for all sites (except New Delhi) ranges from 1981-2011 (1984-2010)

(DSSAT v4.5) was used for wheat yield simulations. The genotypic coefficients for different wheat varieties were selected by repeated iterations using field experimental data for the four sites until a close match between simulated and observed yield was attained. Model efficiency was determined by comparing observed and simulated yields using statistical tools like normalized root mean square error (nRMSE) and D-index (Wilmott et al., 1985).

\section{Climate change projections}

Representative concentration pathways (RCP), the latest generation of scenarios that provide input to climate models consist of four climate change scenarios viz. RCP 8.5, RCP 6, RCP 4.5 and RCP 2.6 that describe four possible future climates, among which India follows RCP 4.5 (Garg et al., 2015). The projected $\mathrm{CO}_{2}$ concentrations for $\mathrm{RCP} 4.5$ were 440,530 and 570 ppm by 2025, 2050 and 2075s, respectively. These $\mathrm{CO}_{2}$ projections were used in simulating future wheat yield whereas observed concentration was used for baseline scenario. In the present analysis, we used projected daily weather from three global circulation model's (GFDL-ESM2M, MIROC5, and NorESM1-M) for three future climatic scenarios. These models were developed as part of the Coupled Model Inter-comparison Project 5 (CMIP5), which is a framework for coordinated climate change experiments. Based on the bias, temporal and spatial correlations, and coefficient of variation in the model output and the observed data, GFDL-ESM2M, MIROC5, and 
Table 2: Genotypic coefficients used for different wheat varieties

\begin{tabular}{lllllllll}
\hline Site & Cultivar & \multicolumn{7}{c}{ Genotypic coefficient } \\
& & P1V & P1D & P5 & G1 & G2 & G3 & PHINT \\
\hline Ludhiana & PBW-343 & 14.7 & 71.1 & 740 & 15 & 60 & 1.0 & 100 \\
Raipur & GW-273 & 10 & 50 & 600 & 19 & 42 & 1.0 & 96 \\
Akola & AKW-1071 & 14 & 66.3 & 630 & 15 & 32.7 & 1.0 & 60 \\
New Delhi & HD-2329 & 0.5 & 91 & 500 & 30 & 59 & 1.0 & 100 \\
\hline
\end{tabular}

PIV - Vernalization coefficient; PID - Photoperiodism coefficient; P5 - Grain-filling duration coefficient; G1 - Kernel number coefficient; G2 - Kernel weight coefficient; G3 - Spike number coefficient; PHINT - Phyllochron interval

Table 3: Observed and simulated crop phenology (DAS) and grain yields $\left(\mathrm{kg} \mathrm{ha}^{-1}\right)$ during baseline period

\begin{tabular}{|c|c|c|c|c|c|}
\hline \multirow[t]{2}{*}{ Site } & \multirow[t]{2}{*}{ Variable name } & \multicolumn{2}{|c|}{ Mean } & \multirow[t]{2}{*}{ nRMSE (\%) } & \multirow[t]{2}{*}{ D-index } \\
\hline & & Observed & Simulated & & \\
\hline \multirow[t]{3}{*}{ Ludhiana } & Anthesis & 111 & 113 & 3 & 0.72 \\
\hline & Yield & 4273 & 3641 & 17 & 0.5 \\
\hline & Maturity & 155 & 155 & 2 & 0.88 \\
\hline \multirow[t]{3}{*}{ Raipur } & Anthesis & 74 & 75 & 3 & 0.83 \\
\hline & Yield & 2236 & 2073 & 20 & 0.7 \\
\hline & Maturity & 108 & 106 & 3 & 0.77 \\
\hline \multirow[t]{3}{*}{ Akola } & Anthesis & 80 & 81 & 3 & 0.81 \\
\hline & Yield & 2283 & 2318 & 20 & 0.5 \\
\hline & Maturity & 112 & 111 & 2 & 0.86 \\
\hline \multirow[t]{3}{*}{ New Delhi } & Anthesis & 108 & 108 & 3 & 0.7 \\
\hline & Yield & 4447 & 4244 & 10 & 0.62 \\
\hline & Maturity & 135 & 136 & 2 & 0.76 \\
\hline
\end{tabular}

NorESM1-M are stated to represent the Indian monsoon as well as air temperature among other CMIP5 models in a better way (Garg et al., 2015). Projected daily weather data was downloaded from MarkSim DSSAT weather file generator (http://gisweb.ciat.cgiar.org/MarkSimGCM/).

\section{Adaptation strategies}

Three crop management options, independently and in combination were tested as adaptation strategies to sustain wheat productivity in future climates. Six sowing time options $(15,10,5$ days ahead and $5,10,15$ days delayed relative to normal sowing time) is the first low-cost option tried. Three nitrogen fertilizer ( $\mathrm{N}$-fertilizer) levels (100, 150 and $200 \%$ of the recommended sites specific $\mathrm{N}$-fertilizer dose) and one additional irrigation between 40-60 days after sowing (DAS) depending on the site. The net effect of each adaptation strategy was assessed in terms of relative yield as

Relative yield $=\left(\frac{\mathrm{Y}_{f a}-\mathrm{Y}_{b}}{\mathrm{Y}_{b}}\right) * 100$ where $\mathrm{Y}_{f a}$ and $\mathrm{Y}_{b}$ indicates future and baseline yield with and without any adaptation, respectively.

\section{RESULTS AND DISCUSSION}

\section{Calibration of CERES-Wheat model}

The CERES-Wheat model was calibrated using the GENCALC software embedded in DSSAT v4.5 for different wheat varieties (PBW-343, GW-273, AKW-1071, HD-2329) at respective experimental sites. The calibrated genetic coefficients of different wheat varieties at respective sites are presented in Table 2 and the statistical results are shown in Table 3. The simulated phenology (days to anthesis and maturity) is in close agreement with observed values at all sites as seen from high $\mathrm{D}$-index values and minimum nRMSE values.

\section{Climate change projections at different sites}

The average percentage change in $\mathrm{T}_{\max }, \mathrm{T}_{\min }$ and 
Table 4: Per cent change in temperature (maximum and minimum) and rainfall over baseline during wheat growing season

\begin{tabular}{|c|c|c|c|c|c|c|c|c|c|c|c|c|c|c|}
\hline \multirow[t]{2}{*}{ Site } & \multirow{2}{*}{$\begin{array}{l}\text { Weather } \\
\text { Variable }\end{array}$} & \multicolumn{4}{|c|}{$2025-26$} & \multicolumn{4}{|c|}{$2050-51$} & \multicolumn{4}{|c|}{$2075-76$} & \multirow{2}{*}{$\begin{array}{r}\text { Overall } \\
\text { Mean }\end{array}$} \\
\hline & & CCS-1 & CCS-2 & CCS-3 & Mean & CCS-1 & CCS-2 & CCS-3 & Mean & CCS-1 & CCS-2 & CCS-3 & Mean & \\
\hline \multirow[t]{3}{*}{ Ludhiana } & $\mathrm{T}_{\max }$ & 10 & 12 & 10 & 11 & 13 & 20 & 15 & 16 & 17 & 24 & 16 & 19 & 15 \\
\hline & $\mathrm{T}_{\min }$ & -8 & 0 & -6 & -5 & -2 & 17 & 4 & 6 & 4 & 24 & 5 & 11 & 4 \\
\hline & Rainfall & 23 & 49 & 68 & 47 & 26 & -52 & 250 & 75 & 47 & 38 & 229 & 105 & 76 \\
\hline \multirow[t]{3}{*}{ Raipur } & $\mathrm{T}_{\max }$ & 1 & -1 & 0 & 0 & 3 & 1 & 2 & 2 & 6 & 5 & 1 & 4 & 2 \\
\hline & $\mathrm{T}_{\min }$ & 14 & 11 & 11 & 12 & 19 & 19 & 15 & 18 & 25 & 25 & 12 & 21 & 17 \\
\hline & Rainfall & -46 & -49 & -20 & -38 & -10 & 17 & -75 & -23 & 3 & 15 & 26 & 15 & -15 \\
\hline \multirow[t]{3}{*}{ Akola } & $\mathrm{T}_{\max }$ & 3 & 2 & 2 & 2 & 5 & 7 & 5 & 6 & 9 & 10 & 4 & 8 & 5 \\
\hline & $\mathrm{T}_{\min }$ & 18 & 18 & 18 & 18 & 22 & 27 & 22 & 24 & 27 & 33 & 12 & 24 & 22 \\
\hline & Rainfall & 20 & -7 & -47 & -11 & 10 & -13 & -83 & -29 & -72 & 24 & 40 & -3 & -14 \\
\hline \multirow[t]{3}{*}{ New Delhi } & $\mathrm{T}_{\max }$ & 5 & 4 & 4 & 4 & 8 & 10 & 7 & 8 & 11 & 12 & 8 & 10 & 7 \\
\hline & $\mathrm{T}_{\min }$ & 12 & 9 & 4 & 8 & 16 & 23 & 12 & 17 & 21 & 28 & 10 & 20 & 15 \\
\hline & Rainfall & -22 & 5 & 12 & -2 & -25 & 7 & 16 & -1 & -12 & -36 & 68 & 7 & 1 \\
\hline
\end{tabular}

"-Seasonal (Nov-Mar) mean at Ludhiana, Raipur, Akola for 1981-2011 and at New Delhi for 1984-2010 period CCS - Climate Change Scenario; CCS-1 - GFDL-ESM2M; CCS-2 - MIROC5; CCS-3 - NorESM1-M

Table 5: Changes (\%) in wheat yield in different climate scenarios at four sites without any adaptation

\begin{tabular}{llrrr}
\hline Site & Scenario & $2025-26$ & $2050-51$ & $2075-76$ \\
\hline Ludhiana & GFDL-ESM2M & -6 & -1 & 7 \\
& MIROC5 & -22 & -22 & -24 \\
& NorESM1-M & -26 & -7 & -3 \\
\multirow{5}{*}{ Raipur } & Mean & -18 & -10 & -7 \\
& GFDL-ESM2M & -23 & -23 & -29 \\
& MIROC5 & -31 & -19 & -25 \\
NorESM1-M & -29 & -31 & -19 \\
& Mean & -28 & -24 & -24 \\
& GFDL-ESM2M & -7 & -18 & -5 \\
& MIROC5 & -3 & -4 & 20 \\
& NorESM1-M & -9 & -6 & -3 \\
& Mean & -6 & -9 & 9 \\
& GFDL-ESM2M & -1 & 10 & -10 \\
& MIROC5 & -10 & -7 & 18 \\
& NorESM1-M & 15 & 17 & 6 \\
\hline
\end{tabular}

rainfall projected by three models over baseline during the wheat growing season in 2025, 2050 and 2075 at four experimental sites are summarized in Table $4 . \mathrm{T}_{\max }$ is projected to rise to a greater extent at Ludhiana in all three future climatic periods among different sites. Contrary to $\mathrm{T}_{\max }$, projected rise in $\mathrm{T}_{\min }$ is explicit at Akola and Raipur in all three climatic periods and it became more distinct towards end of the $21^{\text {st }}$ century at all sites. Rainfall is generally projected to increase at Ludhiana in all three future climatic periods whereas it is projected to decrease at Akola. Conversely, a 
Table 6: Anticipated changes in wheat phenology, $\mathrm{T}_{\max }$ and $\mathrm{T}_{\min }$ in future climates over baseline

\begin{tabular}{|c|c|c|c|c|c|c|c|c|c|c|}
\hline \multirow[t]{2}{*}{ Parameter } & \multicolumn{3}{|c|}{$2025-26$} & \multicolumn{3}{|c|}{$2050-51$} & \multicolumn{3}{|c|}{$2075-76$} & \multirow[t]{2}{*}{ Mean } \\
\hline & CCS-1 & $\mathrm{CCS}-2$ & $\mathrm{CCS}-3$ & CCS-1 & $\mathrm{CCS}-2$ & CCS-3 & CCS-1 & $\mathrm{CCS}-2$ & $\mathrm{CCS}-3$ & \\
\hline \multicolumn{11}{|l|}{ Ludhiana } \\
\hline Days to anthesis & 0 & 2 & 3 & 2 & -4 & 0 & 0 & -8 & -1 & -1 \\
\hline Days to maturity & -2 & -2 & -1 & -2 & -8 & -4 & -4 & -11 & -3 & -4 \\
\hline $\mathrm{T}_{\max }{ }^{*}$ & 0.1 & 1 & 1.6 & 1.3 & 1.4 & 1.5 & 1.7 & 0.8 & 0.4 & 1.1 \\
\hline $\mathrm{T}_{\min }^{\#}$ & -0.7 & 0.2 & 0.3 & 0.3 & 0.2 & 0.4 & 0.5 & -0.1 & -0.2 & 0.1 \\
\hline \multicolumn{11}{|l|}{ Raipur } \\
\hline Days to anthesis & -3 & -2 & -2 & -6 & -3 & -4 & -8 & -7 & -4 & -4 \\
\hline Days to maturity & -9 & -7 & -7 & -11 & -10 & -10 & -13 & -13 & -9 & -10 \\
\hline $\mathrm{T}_{\max }{ }^{*}$ & 0.3 & -0.4 & 0.2 & -0.2 & 0.9 & 0.3 & 0.6 & 1 & -0.4 & 0.3 \\
\hline $\mathrm{T}_{\min } \#$ & 3.2 & 2.4 & 2.8 & 2.7 & 3.7 & 2.7 & 3.2 & 3.2 & 1.5 & 2.8 \\
\hline \multicolumn{11}{|l|}{ Akola } \\
\hline Days to anthesis & -2 & -3 & -2 & -6 & -6 & -4 & -7 & -8 & -5 & -5 \\
\hline Days to maturity & -5 & -5 & -4 & -9 & -9 & -7 & -11 & -12 & -7 & -8 \\
\hline $\mathrm{T}_{\max }{ }^{*}$ & 1.3 & 0.7 & 0.9 & 1.3 & 2.4 & 1.5 & 2.2 & 2.6 & 0.4 & 1.5 \\
\hline $\mathrm{T}_{\min }^{\#}$ & 1.3 & 0.7 & 1.3 & 1.5 & 1.8 & 1.6 & 2 & 2.1 & -0.2 & 1.4 \\
\hline \multicolumn{11}{|l|}{ New Delhi } \\
\hline Days to anthesis & -1 & -1 & 1 & -1 & -6 & -2 & -3 & -7 & -3 & -3 \\
\hline Days to maturity & -1 & -1 & 0 & -2 & -6 & -2 & -4 & -7 & -3 & -3 \\
\hline $\mathrm{T}_{\max }{ }^{*}$ & 1.2 & 1.2 & 2.2 & 2.1 & 1.7 & 2.1 & 2.9 & 1.8 & 1.5 & 1.8 \\
\hline $\mathrm{T}_{\min }^{\#}$ & 1.9 & 1.1 & 1.5 & 2.2 & 2 & 1.7 & 2.5 & 2.1 & 1 & 1.8 \\
\hline
\end{tabular}

*,\#- Mean temperature during post-anthesis to maturity decrease is projected at Raipur and New Delhi in 2025 and 2050, which turned positive in 2075. Thus, wheat crop is likely to receive more rainfall at Ludhiana $(+76 \%)$ in future climates and experience warmer daytime temperature at Ludhiana $(+15 \%)$ and warmer nights at Raipur $(+17 \%)$ and Akola $(+22 \%)$. The projected climate change scenarios by the three models in the present study confirm the earlier projections reported by Kumar et al. (2013).

\section{Simulated wheat yield in future climates}

The future wheat yields simulated using three different climate change scenarios with existing fertilizer $(100 \%$ NPK) and irrigation schedule at each experimental site without any adaptation strategy is presented in Table 5 . Except for New Delhi, wheat yields are likely to decline steeply in all three scenarios. In 2025 and 2050, all the three climate change scenarios projected a decline in yields over the baseline at all sites, except at New Delhi, whereas in 2075 at least one among the three models predicted an increase in yield over the baseline at all the sites, except at Raipur. In

fact, Raipur is the only site where in all the climate scenarios yield decline was projected over baseline yields. In NorESM1-M climate change scenario, a positive effect on wheat yield in all the three future scenarios at New Delhi is noticed. In broad sense, it could be inferred that projected changes in wheat yield at New Delhi site is highly inconsistent. However, it is quite clear that wheat yields in future are likely to decline in absence of adaptation options for major wheat growing regions.

To have a better insight on the inconsistency in projected yield in different scenarios, we compared changes in the crop growth projected by all models and presented in Table 6. A pronounced shortening of crop duration at Raipur (7-9 days) followed by Akola (4-5 days) and Ludhiana sites (1-2 days) in 2025 is projected. Crop duration further shortened by 10 to 11 and 9 to 13 at Raipur, 7 to 9 and 7 to 12 at Akola and 2 to 4 and 3 to 11 at Ludhiana sites during 2050 and 2075, respectively. This shortening of crop duration has led to a reduction in the yield across these sites. However, 
Table 7: Ideal adaptation strategies for different climate scenarios and periods at the four sites

\begin{tabular}{|c|c|c|c|c|c|c|c|c|c|c|c|c|c|}
\hline \multirow[t]{5}{*}{ Site } & \multirow{5}{*}{$\begin{array}{l}\text { Climate } \\
\text { change } \\
\text { scenario }\end{array}$} & \multicolumn{12}{|c|}{ Relative yield in response to different adaptation strategies } \\
\hline & & \multicolumn{4}{|c|}{$2025-26$} & \multicolumn{4}{|c|}{$2050-51$} & \multicolumn{4}{|c|}{$2075-76$} \\
\hline & & $\mathrm{N}_{100}$ & $\mathrm{~N}_{100}$ & $\mathrm{~N}_{150}$ & $\mathrm{~N}_{200}$ & $\mathrm{~N}_{100}$ & $\mathrm{~N}_{100}$ & $\mathrm{~N}_{150}$ & $\mathrm{~N}_{200}$ & $\mathrm{~N}_{100}$ & $\mathrm{~N}_{100}$ & $\mathrm{~N}_{150}$ & $\mathrm{~N}_{200}$ \\
\hline & & $\mathrm{N}_{\mathrm{r}} \mathrm{I}_{\mathrm{r}}$ & $\mathrm{E}_{\mathrm{r}} \mathrm{I}_{\mathrm{r}}$ & $\mathrm{E}_{\mathrm{r}} \mathrm{r}_{\mathrm{r}}$ & $\mathrm{E}_{\mathrm{rr}}$ & $\mathrm{N}_{\mathrm{r}} \mathrm{I}_{\mathrm{r}}$ & $\mathrm{E}_{\mathrm{r}} \mathrm{r}_{\mathrm{r}}$ & $\mathrm{E}_{\mathrm{r}} \mathrm{I}_{\mathrm{r}}$ & $\mathrm{E}_{\mathrm{r} r}$ & $\mathrm{~N}_{\mathrm{r}} \mathrm{r}_{\mathrm{r}}$ & $\mathrm{E}_{\mathrm{r}} \mathrm{I}_{\mathrm{r}}$ & $\mathrm{E}_{\mathrm{r}} \mathrm{I}_{\mathrm{r}}$ & $\mathrm{E}_{\mathrm{r}} \mathrm{r}_{\mathrm{r}}$ \\
\hline & & $\mathrm{AS}_{15}$ & $\mathrm{~N}_{\mathrm{r}} \mathrm{S}_{0}$ & $\mathrm{AS}_{5}$ & $\mathrm{AS}_{10}$ & $\mathrm{AS}_{15}$ & $\mathrm{~N}_{\mathrm{r}} \mathrm{S}_{0}$ & $\mathrm{AS}_{5}$ & $\mathrm{AS}_{10}$ & $\mathrm{AS}_{15}$ & $\mathrm{~N}_{\mathrm{r}} \mathrm{S}_{0}$ & $\mathrm{AS}_{5}$ & $\mathrm{AS}_{10}$ \\
\hline \multirow[t]{4}{*}{ Ludhiana } & GFDL-ESM2M & -20 & -3 & -1 & 9 & -17 & 2 & -2 & 17 & -11 & 6 & 9 & 15 \\
\hline & MIROC5 & -26 & -20 & -10 & 5 & -27 & -14 & 1 & 9 & -5 & -19 & 0 & 2 \\
\hline & NorESM1-M & -17 & -22 & -3 & 9 & -17 & -13 & -5 & 8 & 1 & -2 & 7 & 21 \\
\hline & Mean & -21 & -15 & -4 & 7 & -20 & -8 & -2 & 11 & -5 & -5 & 5 & 13 \\
\hline \multirow[t]{4}{*}{ Raipur } & GFDL-ESM2M & -28 & 3 & 0 & -4 & -24 & 4 & 0 & 4 & -18 & -6 & 7 & -5 \\
\hline & MIROC5 & -20 & -7 & 11 & 9 & -24 & 4 & 0 & 33 & -20 & -2 & 3 & 22 \\
\hline & NorESM1-M & -28 & 4 & -6 & 4 & -26 & -7 & 1 & 0 & -23 & 6 & 41 & 36 \\
\hline & Mean & -26 & -3 & 2 & 0 & -24 & -2 & 0 & 13 & -20 & 0 & 17 & 18 \\
\hline \multirow[t]{4}{*}{ Akola } & GFDL-ESM2M & -10 & 17 & 21 & 26 & 5 & 6 & 26 & 29 & -24 & 1 & 11 & 9 \\
\hline & MIROC5 & 1 & 21 & 24 & 26 & -3 & 18 & 5 & 20 & 9 & 20 & 12 & 26 \\
\hline & NorESM1-M & -3 & 15 & 20 & 25 & -13 & 22 & 25 & 25 & 13 & 42 & 54 & 54 \\
\hline & Mean & -4 & 18 & 22 & 26 & 4 & 15 & 19 & 25 & -1 & 21 & 26 & 29 \\
\hline \multirow[t]{4}{*}{ New Delhi } & GFDL-ESM2M & 0 & 0 & 13 & 20 & 15 & 10 & 22 & 35 & 20 & 11 & 30 & 40 \\
\hline & MIROC5 & 0 & -3 & 5 & 3 & 7 & -3 & 8 & 15 & 7 & 0 & 12 & 26 \\
\hline & NorESM1-M & 10 & 14 & 21 & 15 & 25 & 16 & 26 & 22 & 31 & 16 & 23 & 28 \\
\hline & Mean & 4 & 4 & 13 & 12 & 15 & 8 & 19 & 24 & 19 & 9 & 22 & 31 \\
\hline
\end{tabular}

$\mathrm{N}_{100}, \mathrm{~N}_{150}, \mathrm{~N}_{200}-100 \%, 150 \%, 200 \%$ recommended N; $\mathrm{N}_{\mathrm{r}} \mathrm{I}$ - Site-specific normal irrigations; E I -One extra irrigation@40-60 DAS; $\mathrm{N}_{\mathrm{r}} \mathrm{S}_{0}$ - Site-specific normal date of sowing; $\mathrm{AS}_{5}, \mathrm{AS}_{10}, \mathrm{AS}_{15}$ - Advanced sowing by 5,10 and 15 days relative to normal date of sowing

at New Delhi, no change in crop duration in 2025 is projected, whereas it decreased by 2 and 3 days, in 2050 and 2075 respectively by NorESM1-M. The distinct shortening of duration between anthesis to maturity period at Raipur and Akola might be a result of projected rise in $\mathrm{T}_{\min }$ at these sites in future climate scenarios. Apart from shortening of the maturity period, the heat stress that arises due to a rise in $\mathrm{T}_{\max }$ and $\mathrm{T}_{\min }$ during crop season is likely to exert a strong influence on yields.

Global wheat production is estimated to fall by 6 per cent for each $1{ }^{\circ} \mathrm{C}$ rise in temperature (Asseng et al., 2015), whereas in India it was estimated to reduce by 10 per cent in major wheat producing states of Punjab, Haryana and Uttar Pradesh if the winters become warmer by $0.5^{\circ} \mathrm{C}$ (Khan et al., 2009). It is interesting to note that the overall magnitude of decline in wheat yields at Ludhiana (-18\%) and Raipur ($28 \%$ ) site would be more in near future i.e. in 2025 as compared successive climatic periods (2050 and 2075). This could be ascribed to positive effect of increasing atmospheric $\mathrm{CO}_{2}$ on photosynthesis and consequently productivity of wheat. Nonhebel (1996) reported doubling of the $\mathrm{CO}_{2}$ concentration caused an increase in yield of 40 per cent due to higher assimilation rates.

\section{Impact of adaptation strategies}

The objective of our study was to assess changes in wheat yields under climate change and identify opportunities, which must be overcome, to sustain wheat yields in the future climates of India. In the present investigation, we tried three management options to minimize the negative impacts of climate change and the details of each are discussed below.

Response to change in sowing time: The impact of six different sowing dates (three early and three late sowings at an interval of five days) with respect to normal date of 


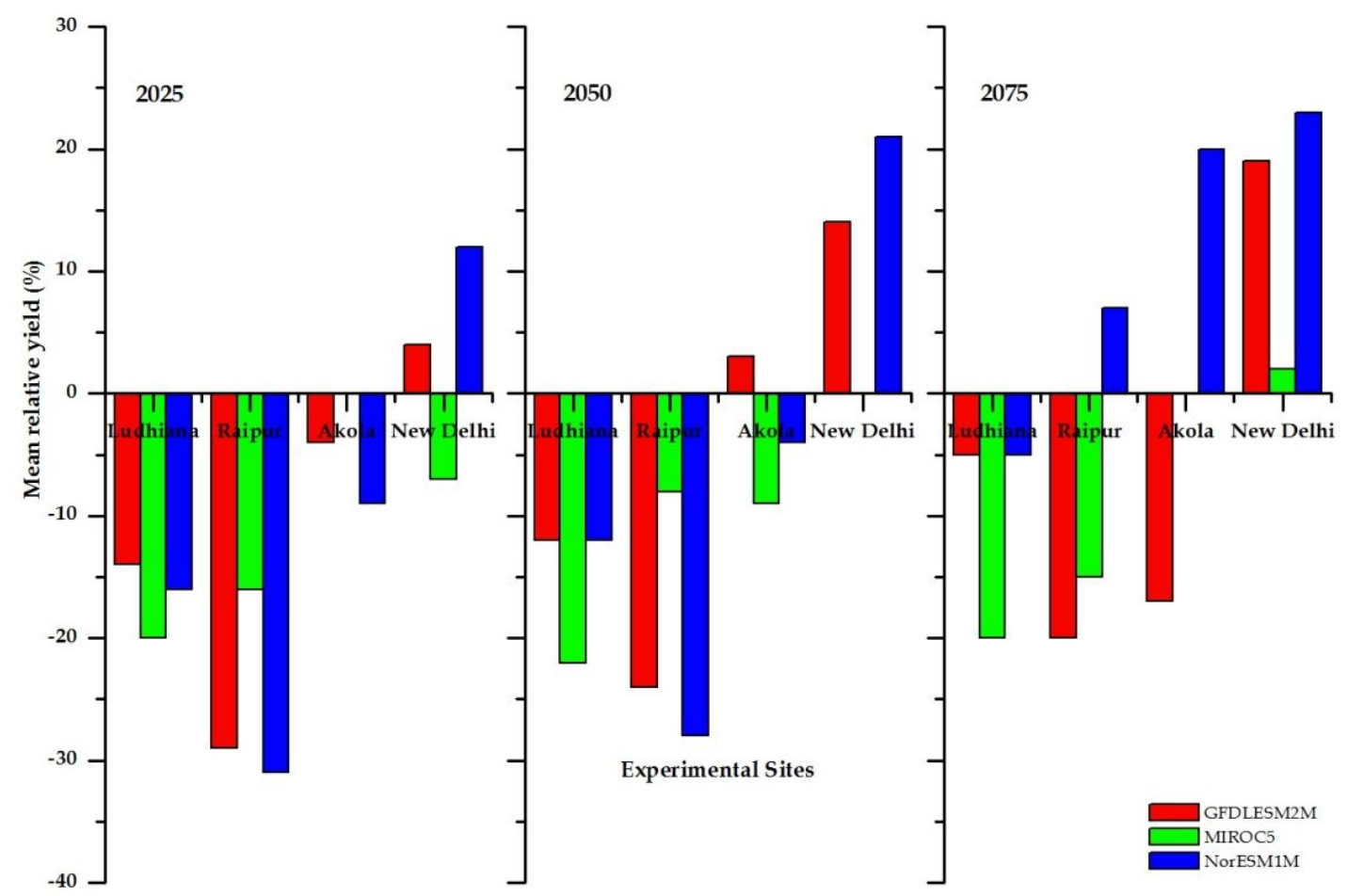

Fig. 1: Mean relative yield of three advance sowings under three climate scenarios in 2025, 2050 and 2075

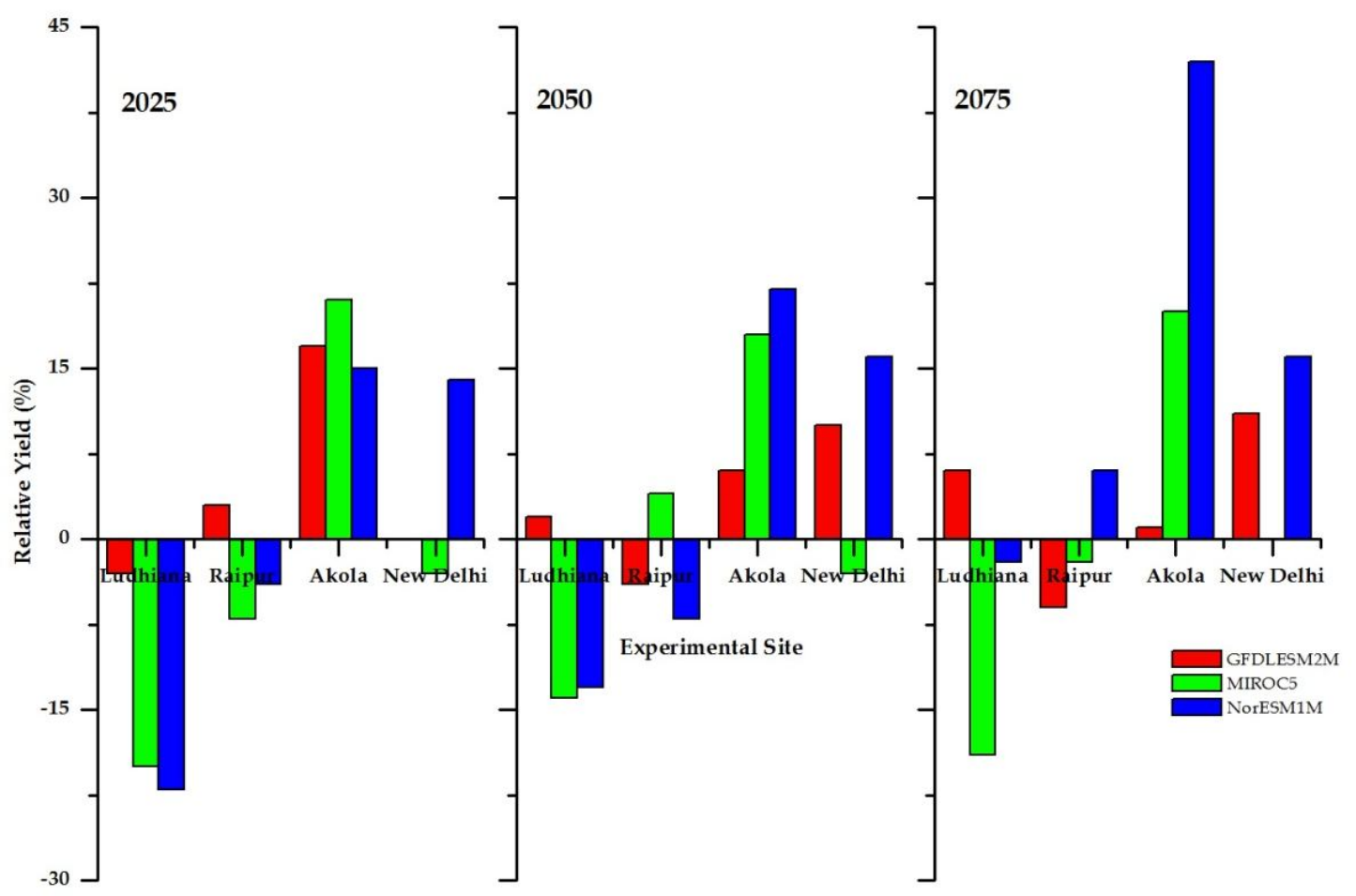

Fig. 2: Relative yield in response to one extra irrigation under three climate scenarios in 2025, 2050 and 2075 


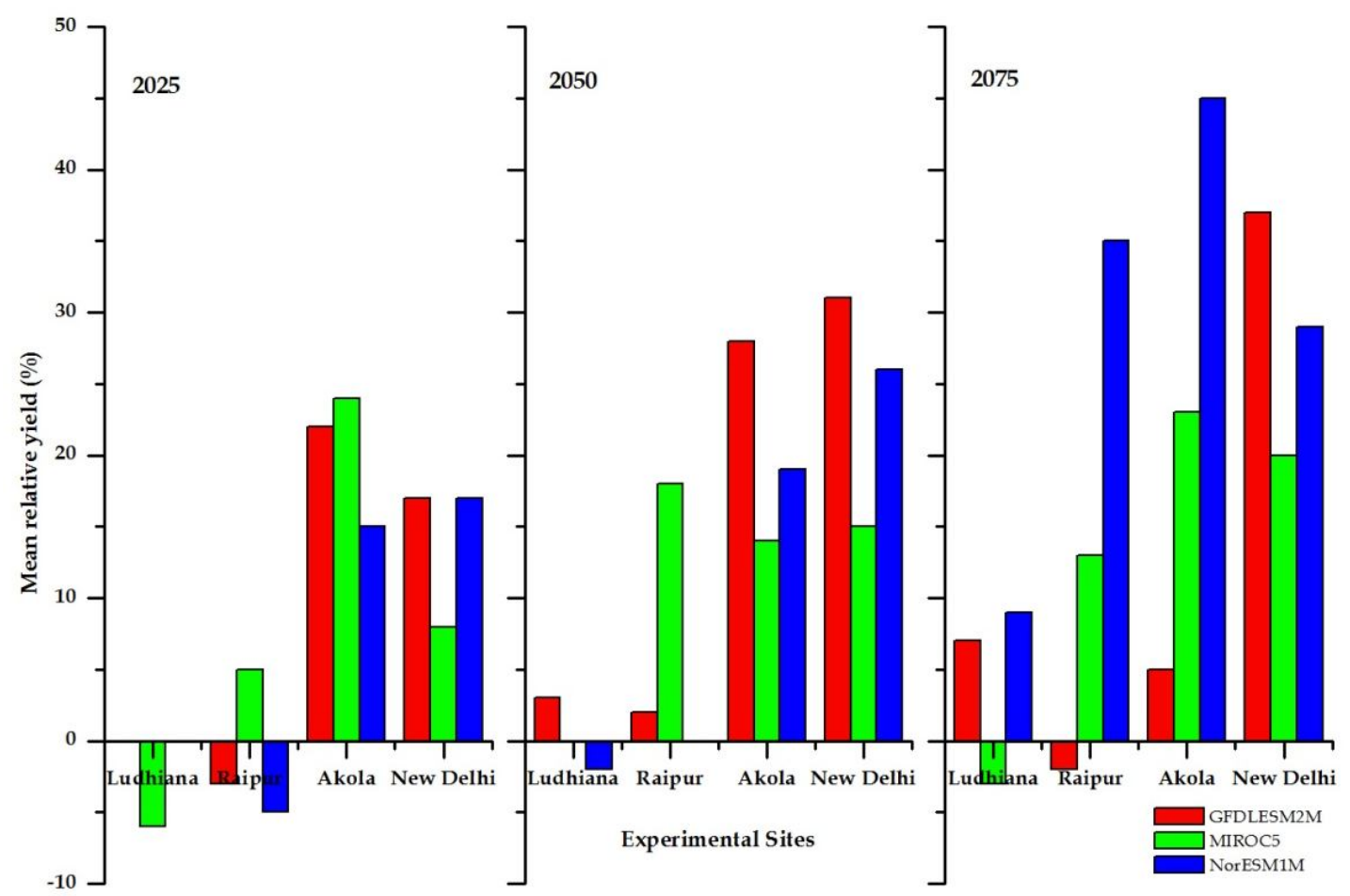

Fig. 3: Mean relative yield of three advance sowings in response to $150 \% \mathrm{~N}$-fertilizer and one extra irrigation under three climate scenarios in 2025, 2050 and 2075

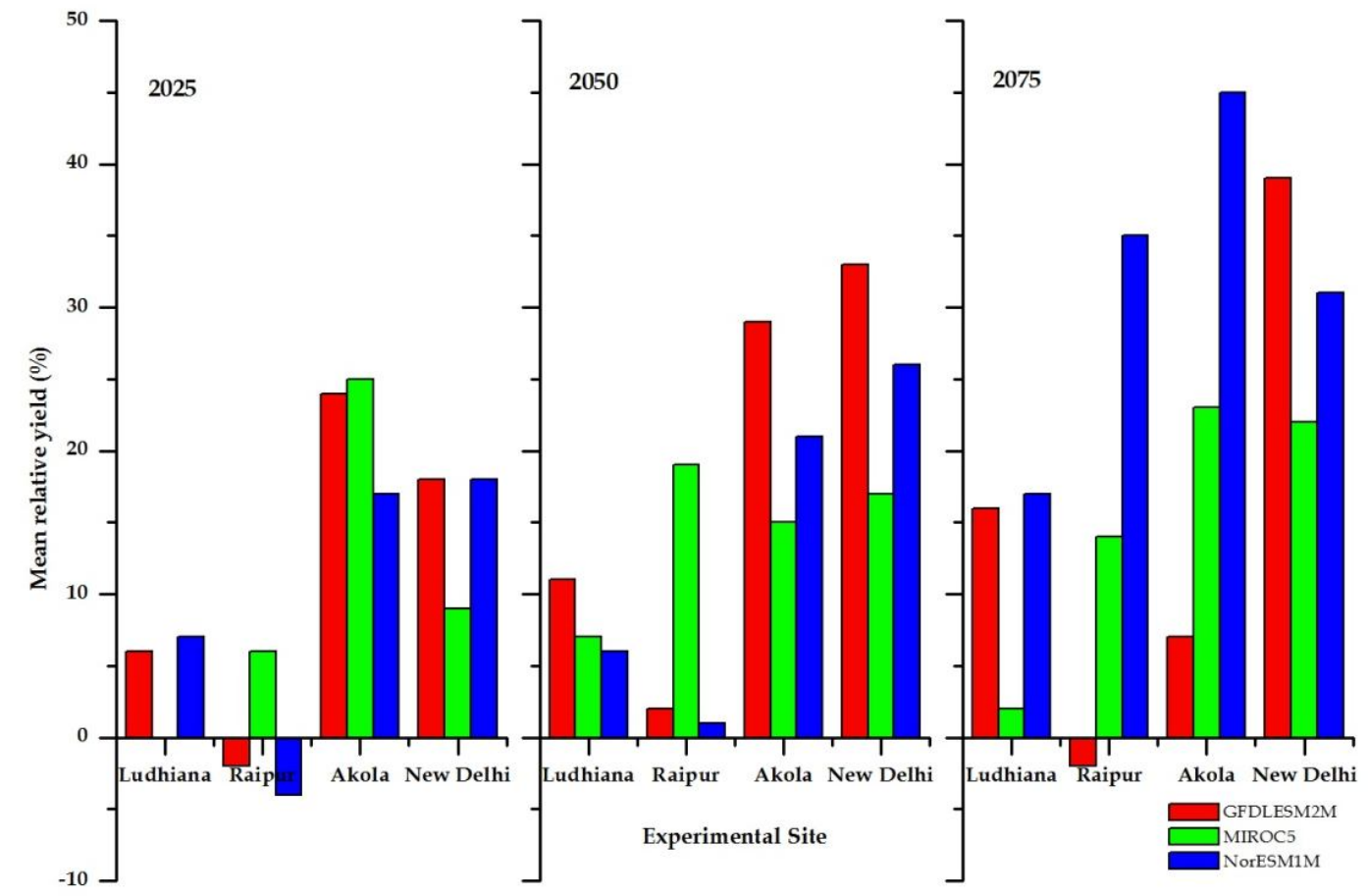

Fig. 4: Mean relative yield of three advance sowings in response to $200 \% \mathrm{~N}$-fertilizer and one extra irrigation under three climate scenarios in 2025, 2050 and 2075 
sowing at each experimental site was assessed. Among the four sites, beneficial effect of advancement of sowing time on wheat productivity was noticed only at New Delhi (Fig. 1). It appeared that advancement of sowing time at New Delhi has an advantage in reducing the terminal heat stress. This might be the reason behind the marginal reduction in the duration from anthesis to maturity. The average rise in $\mathrm{T}_{\max }$ projected by three models at Ludhiana, Raipur, and Akola for 2025 is 11,0 and 2 per cent over the base period (Table 4) where at New Delhi it is 4 per cent. In case of $\mathrm{T}_{\text {min }}$, the rise on an average is more at Akola and Raipur compared to New Delhi. Our analysis indicated that response to adjusting sowing time is a site specific management option as the response is not uniform across the sites assessed and could not compensate the yield losses. The differential rise in day and night temperatures at different sites could be another reason for this response. The projected rise in $\mathrm{CO}_{2}$ concentration failed to offset the detrimental effect of a rise in $\mathrm{T}_{\max } / \mathrm{T}_{\min }$ temperatures. On average for three future scenarios, the period from anthesis to maturity was shortened by 10 days with a rise in $\mathrm{T}_{\min }$ by $2.8^{\circ} \mathrm{C}$ at Raipur and by 8 days with an average rise in $\mathrm{T}_{\min }$ by $1.4{ }^{\circ} \mathrm{C}$ at Akola (Table 6). However, the rise in $\mathrm{T}_{\max }$ on an average for three climatic scenarios was more than $1{ }^{\circ} \mathrm{C}$ at Ludhiana and New Delhi, its effect on the days from anthesis to maturity is relatively small. This could be due to prevailing $\mathrm{T}_{\max }$ are lower than the threshold. Kalra et al. (2013) indicated the optimum sowing time gets advanced by $5-8$ days per ${ }^{\circ} \mathrm{C}$ rise in temperature under Indian conditions.

Response to change in irrigation scheduling : Projected changes in growing season rainfall in future climates is not uniform across sites studied. Apart from these, an increase in temperature generally leads to an increase in evapotranspiration demands. The cumulative seasonal evapotranspiration is comprehensively controlled by temperature, rainfall, and crop duration. Keeping the variability in seasonal rainfall among the sites, we opted for an additional irrigation as one of the adaptation strategies to alleviate heat stress effects on wheat productivity. With an extra irrigation of $75 \mathrm{~mm}$ applied $60 \mathrm{DAS}$, the yields were improved in all three climatic scenarios only at Akola with respect to normal date of sowing (Fig. 2). Again, the response to additional irrigation in future climate is not uniform across the sites, which could be due to differences in projected rainfall amounts.

Response to combined changes in management options : Since the crop response to fertilizer is dependent on soil moisture availability, optimizing $\mathrm{N}$-fertilizer in future climates is a deciding factor in terms of cost-benefit ratio. A possibility exists where shortening of duration from anthesis to maturity due to heat stress can be compensated with additional biomass accumulation by making more nitrogen and water availability to the crop. Increased $\mathrm{N}$ availability results in an increased number of grains through increased number of fertile florets and the per cent of them setting into grains (Semenov et al., 2014). If the grain filling period coincides with low water availability then uptake of available soil nitrogen could be reduced substantially (Semenov et al., 2007). In well fertilized and irrigated conditions without initial water stress, crop will accumulate more biomass and a potentially high yield. However, if it is exposed to heat stress late in the season grain filling and yields will be reduced (Asseng et al., 2015). Adaptation options like change in sowing time, increased $\mathrm{N}$-fertilization and irrigation could compensate for some of the negative impacts of climate change on maize (Kassie et al., 2015). Such studies on combined response of wheat to increased irrigation and nitrogen fertilization in projected climates are very few.

Additional $\mathrm{N}$-fertilization alone did not improve the yield appreciably over baseline (Results are not reported here). When both $\mathrm{N}$ and irrigation were together incremented, the response was distinct. At Raipur, advance sowing with increased $\mathrm{N}$ - fertilizer (150\%) and one additional irrigation applied at 40-60 DAS, improved wheat yields in all scenarios and periods (except NorESM1-M in 2025) projected (Fig. $3)$. Highest relative yield was realized at Ludhiana when sowing was advanced with doubled $\mathrm{N}$-fertilizer $(200 \% \mathrm{~N})$ and one extra irrigation (Fig. 4). An ideal management option for all the three climatic scenarios and periods for the four sites are summarized in Table 7.

\section{CONCLUSION}

Projected changes in day and night temperatures at four sites representing three major wheat growing ecologies of India are diverse both in direction and magnitude. Day temperature is expected to rise conspicuously at Ludhiana representing northwest parts of the country and moderately over central parts of India at Akola and Raipur. Similar is the case with rainfall projections, with positive anomalies projected for Ludhiana and negative at Raipur. With these anticipated changes, wheat is likely to experience warmer days at Ludhiana and nights at Raipur and more moisture availability at Ludhiana in future climates. Negative impacts of climatic change over major wheat growing areas of India 
can be minimized by adapting one or a combination of management practices like adjusting sowing time, revising irrigation and fertilizer scheduling which are site specific as elicited from the present investigation. All these management practices are aimed to escape from the extreme events which may prove beneficial in the short term. In the long run, breeding strategies for evolving varieties with improved heat stress tolerance with more efficient root system and architecture may alleviate climate change impacts on wheat.

\section{REFERENCES}

Asseng, S., Ewert, F., Martre, P., Rötter, R.P., Lobell, D.B., Cammarano, D., (2015). Rising temperature reduce global wheat production. Nat. Clim. Change., 5:143-147.

Bapuji Rao, B., Santhibhushan Chowdary, P., Sandeep, V.M., Pramod, V.P. and Rao, V.U.M. (2015). Spatial analysis of the sensitivity of wheat yields to temperature in India. Agric. For. Meteorol., 200:192-202.

Chatrath, R., Mishra, B., Ortiz-Ferrara, G., Singh, S.K. and Joshi, A.K. (2007). Challenges to wheat production in South Asia. Euphytica., 157: 447-456.

DES, (Department of Economics and Statistics, Government of India). (2017). Commodity profile of wheat for January 2017. http://agricoop.nic.in/sites/default/files/ Wheat.pdf.

Garg,A., Mishra Vimal. and Dholakia,H. (2015). Climate change and India: adaptation gap (2015) - A Preliminary Assessment. Working paper of Indian Institute of Management Ahmedabad(IIMA) W.P. No. 2015-11-01.

Godwin, D.C., Ritchie, J.T., Singh, U. and Hunt, L. (1989). A user's guide to CERES-Wheat v2.10. International Fertilizer Development Centre, Muscle Shoals, AL.

Kalra, N., Suneja, P., Mendiratta, N. and Gupta, N. (2013). Simulating the impacts of climate change and its variability on growth and yield of crops. Clim. Change. Environ. Sustain., 1(1):11-19.

Kassie, B.T., Asseng, S., Rotter, R.P., Hengsdijk, H., Ruane,A.C. and Van Ittersum, M.K.(2015). Exploring climate change impacts and adaptation options for maize production in the Central Rift Valley of Ethiopia using different climate change scenarios and crop models. Clim. Change, 129: $145-158$.
Khan, S.K., Sanjeev Kumar., Hussain, M.Z. and Kalra, N. (2009). Climate change, climate variability and Indian agriculture: Impacts vulnerability and adaptation strategies. In: "Climate Change and Crops". (Ed. S.N. Singh).pp 19-38. (Springer-Verlag Berlin Heidelberg).

Kumar, P., Wiltshire, A., Mathison, C., Asharaf, S., Ahrens, B., Lucas-Picher, P., Christensen, J.H., Gobiet, A., Saeed, F., Hagemann, S. and Jacob, D. (2013). Downscaled climate change projections with uncertainty assessment over India using a high resolution multi-model approach. Sci. Total Environ., 468-469: 18-30.

Manju Zacharias., Naresh Kumar, S., Singh, S.D., Swaroopa Rani, D.N. and Aggarwal, P.K. (2014). Assessment of impacts of climate change on rice and wheat in the IndoGangetic plains. J. Agrometeorol., 16(1): 9-17.

Nathaniel, D.M., James, S.G., Matt, J., Deepak, K.R., Navin, R. and Jonathan, A.F. (2012). Closing yield gaps through nutrient and water management. Nature, 490: 254257.

Nonhebel, S. (1996). Effects of temperature rise and increase in $\mathrm{CO}_{2}$ concentration on simulated wheat yields in Europe. Clim. Change, 34: 74-90.

Prasad, R. (2011). Nitrogen and food grain production in India. Ind. J. Fert., 7(12): 66-76.

Sandhu, S.S., Prabhyot-Kaur., Tripathi, P., Patel, S.R., Prasad, R., Solanki, N.S., Kumar, R., Singh, C.B., Dubey,A.P. and Rao, V.U.M. (2016). Effect ofintra-seasonal temperature on wheat at different locations of India: A case study using CERES-Wheat model. J. Agrometeorol., 18(2): 222-233.

Semenov, M.A., Jamieson, P.D. and Martre, P. (2007). Deconvoluting nitrogen use efficiency in wheat: a simulation study. Eur. J. Agron., 26:283-294.

Semenov, M.A., Stratonovitch, P., Alghabari, F. and Gooding, M.J. (2014). Adapting wheat in Europe for climate change. J. Cer. Sci., 59:245-256.

Willmott, C.J.,Ackleson, S.G., Davis, R.E., Feddema, J.J., Klink, K.M., Legates, D.R., O’Donnell, J. and Rowe, C.M. (1985). Statistics for the evaluation and comparison of models. J. Geophys. Res., 90(C5): 8995-9005. 